\title{
Protecting children: the American turn from polio to cancer vaccines
}

\author{
" Cite as: CMAJ 2019 July 2;191:E739-41. doi: 10.1503/cmaj.181630
}

CMAJ Podcasts: audio reading at https://soundcloud.com/cmajpodcasts/181630-medsoc

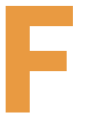

rom 1964 through 1978, the United States poured billions of dollars into an ambitious program larger than the Human Genome Project: developing a human cancer vaccine. This massive program emerged in spite of cancer specialists' continuing denials that human cancer viruses even existed, rather than through their endorsement. ${ }^{1}$ This paradox reveals the extent to which the development of biomedical research follows not only scientific consensus, but also how society understands disease.

Consensus regarding cancer viruses did not shift dramatically between the 1950 s and 1960 s but, in those years, cancer gained fresh notoriety as a threat to children. Framing cancer as a childhood disease changed its social context. The polio vaccination effort of the 1940s had profoundly reshaped American expectations regarding research on childhood diseases by combining promises of biomedical breakthroughs with an insistence on the moral urgency of protecting children. Vaccination against childhood leukemia provided a vital point where this moral urgency passed from one disease to another, transforming cancer research as a whole.

\section{From presidents to poster children}

Polio activists pioneered the sentimental images of vulnerable children that are now ubiquitous in fundraising for disease research. Polio had emerged as a public health problem in the early twentieth century. In the 1930s, President Franklin D. Roosevelt, who had been struck by polio as an adult, used his popularity to raise

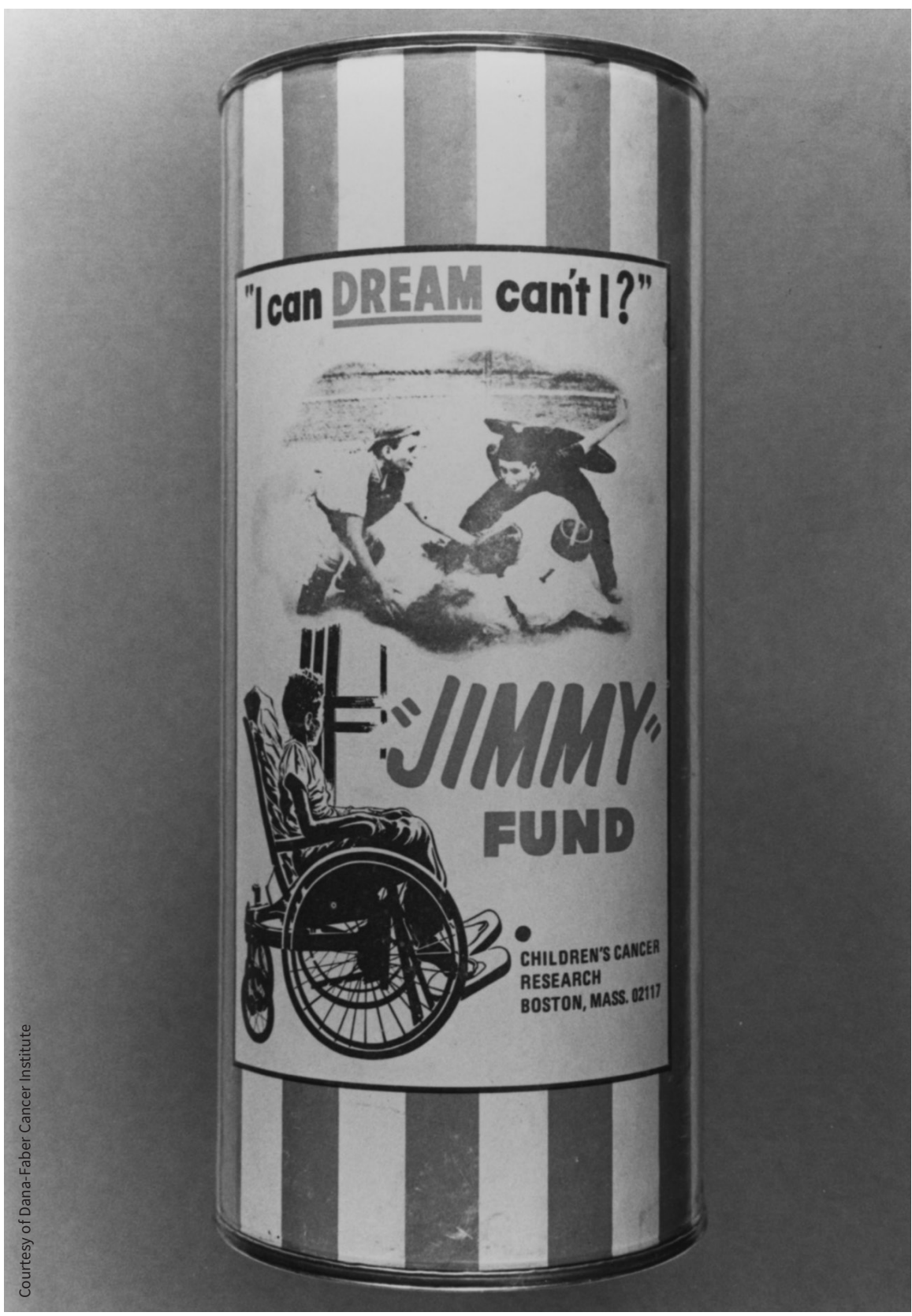

Fundraising for childhood leukemia, such as that pioneered by the Jimmy Fund, drew on iconography developed by the March of Dimes. Image courtesy of Dana-Farber Cancer Institute. 
money for polio rehabilitation through annual birthday fundraisers. However, as political controversies surrounding the New Deal dulled Roosevelt's appeal, his associates sought a new strategy for fundraising. The organization they formed in 1938, the National Foundation for Infantile Paralysis, associated its charitable campaigns with children suffering from polio. ${ }^{2}$

The timing was favourable. The special value of children and childhood had grown steadily during the twentieth century, reflected in children's health campaigns, education and labour protections. During the baby boom after the Second World War, American society placed a premium on nurturing children. Unlike adults, who were regarded as accountable for their health and economic security, American society viewed children as vulnerable innocents. ${ }^{3}$ Appealing to the moral urgency of protecting these children allowed the foundation to raise millions of dollars, underwriting a vast range of research in virology. 2,4,5

Although powerful fundraising icons, children also produced tensions between biomedical researchers and the foundation. Virologists largely understood their mission as being to seek knowledge rather than produce therapies. Fearing

\section{Cancer as a childhood disease}

In the early twentieth century, oncologists were less concerned with finding a cure for cancer, which appeared impossible within their existing techniques, than with the mystery of cancer undermining their standing with the public. The message they offered to the public focused on early detection: adults threatened by cancer bore individual responsibility for noticing cancer's symptoms and seeking treatment, but the medical profession did not have an obligation to eliminate the disease. ${ }^{6,7}$

It was a relative outsider to the cancer community, a pathologist at Boston Children's Hospital named Sidney Farber, who embraced both the goal of curing cancer and the power of children for cancer fundraising. In 1948, Farber started to investigate treatments for childhood leukemia. Unlike the solid tumours often confronted by surgeons, leukemia, a cancer of the blood, could not be treated by radiation or surgery. Inspired by the success of antibiotic chemotherapies for infections, Farber sought to test chemotherapy as a strategy against cancer, eventually producing extraordinary temporary remissions in his patients. ${ }^{8}$

\section{Polio activists pioneered the sentimental images of vulnerable children that are now ubiquitous in fundraising for disease research.}

donor disenchantment if a promised polio cure did not arrive, the foundation dismissed the gradualism of these virologists and sponsored younger scientists, notably Jonas Salk, who were willing to focus directly on the production of a vaccine. ${ }^{2}$ Although we may recall the Salk vaccine as a medical success, it was equally a triumph for a new model of biomedical research that embraced urgency over contemplation. ${ }^{1}$
Faced with his surgical colleagues' skepticism toward chemotherapy, Farber drew on leukemia's association with children in order to expand his research. He sought aid from the Variety Club, a children's charity sponsored by the New England entertainment industry. Farber and the Variety Club created the Children's Cancer Research Foundation, whose campaigns centred on "Jimmy," a child being treated for leukemia. After just four years, Farber moved his activities into the new Jimmy Fund building, which formed the nucleus of today's DanaFarber Cancer Institute. ${ }^{8}$

Although childhood cancers remained a small fraction of all cancer cases, this new presentation of cancer as a threat to children imbued cancer research, especially chemotherapy, with new urgency that traditional cancer researchers struggled to match. This urgency redrew the political boundaries between private philanthropy and government action. In 1946, both the Surgeon General and the American Cancer Society had opposed a popular proposal to create a federal "Manhattan Project" to cure cancer. However, in 1953 the American Cancer Society dropped its opposition to government intervention and started to solicit federal support for chemotherapy research, especially that which might protect children. Congress responded enthusiastically, routing millions of dollars to chemotherapy studies and transforming the National Cancer Institute into the pre-eminent sponsor of cancer research in the world. However, even the progress of chemotherapy in the 1950 s appeared too slow. ${ }^{1,5}$

\section{Speeding up the hunt for cancer viruses}

Even as concern over childhood cancer rose, vaccination remained at the margins of cancer policy. Medical groups viewed the theory that cancer was contagious as counterproductive to their overall aim of reducing the fear that the disease inspired. Experimental studies did not challenge this view. In the 1920s and 1930s, viruses could not be seen through a microscope or cultured outside of animals, let alone associated with human cancer using the standards of microbiology. ${ }^{1}$

Here, polio made its second contribution, generating a new community of scientists to support cancer vaccination. After the Salk vaccine, many virologists supported by the foundation watched their support fall, an unforeseen consequence of the receding threat of polio. Many of their number, including Nobel Prize winners and vaccine developers, 
sensed new funding potential in cancer. This group promised that cancer could be eliminated through vaccination with time, effort and determination. ${ }^{1}$

With the backing of these virologists and the moral urgency of childhood disease research in place, the National Cancer Institute disregarded cancer specialists' skepticism and embraced vaccination. In 1964, it unveiled the Special Virus Leukemia Program, which incorporated military research and development methods to accelerate biomedical research. Justifying this radical approach, the National Cancer Institute's leadership argued that children died every day that leukemia remained uncured. The question was not if a human cancer virus would be found, but of how the Institute would create a vaccine when these viruses were discovered. During the War on Cancer of the 1970s, the program's ambitious methods provided the core of the National Cancer Institute's multibillion-dollar hunt for cancer viruses. $^{1}$
Although today it appears that vaccination might help prevent as many as one in six cancers globally through prevention of chronic infections that cause cancers, the National Cancer Institute's effort did not reveal a generic human cancer virus. Ironically, its hunt for viruses - external carcinogens - gave rise to the molecular oncogene theory of cancer: an enemy within. ${ }^{1}$ Although critics of its planning approach have been quick to label this episode a failure, it is better thought of as a reminder that our judgment of success or failure in biomedical research must reflect an awareness of both its biological nature and social frames. The midcentury call for a cancer vaccine was not answered, but it transformed our understanding of life at a molecular level.

\section{Robin Wolfe Scheffler PhD}

Massachusetts Institute of Technology Program in Science, Technology and Society, Cambridge, Mass.

\section{References}

1. Scheffler RW. A contagious cause: the American hunt for cancer viruses and the rise of molecular medicine. Chicago: University of Chicago Press; 2019.

2. Oshinsky DM. Polio: an American story. Oxford (UK): Oxford University Press; 2005.

3. Zelizer VAR. Pricing the priceless child: the changing social value of children. New York: Basic Books; 1985.

4. Adams V, Murphy M, Clarke AE. Anticipation: technoscience, life, affect, temporality. Subjectivity 2009;28:246-65.

5. Creager ANH. Mobilizing biomedicine: virus research between lay health organizations and the US federal government 1935-1955. In: Hannaway $\mathrm{C}$, editor. Biomedicine in the twentieth century: practices, policies, and politics. Amsterdam: IOS Press; 2008:171-201.

6. Aronowitz RA. Unnatural history: breast cancer and American society. Cambridge (UK): Cambridge University Press; 2007.

7. Wailoo K. How cancer crossed the color line. Oxford (UK): Oxford University Press; 2011.

8. Krueger GM. Hope and suffering: children, cancer, and the paradox of experimental medicine. Baltimore (MD): Johns Hopkins University Press; 2008.

This article was solicited and has been peer reviewed. 